\title{
A study of burrow morphology in representative axiidean and gebiidean mud shrimps, from the Persian Gulf and Gulf of Oman, Iran
}

Vahid Sepahvand, Alireza Sari*, Christopher Tudge and Mehdi Bolouki

(VS, AS) School of Biology and Centre of Excellence in Phylogeny of Living Organisms, College of Science, University of Tehran, Tehran, Iran. E-mail: (AS) sari@ut.ac.ir, *Corresponding author; (VS) sepahvandv@gmail.com

(CT) Biology Department, American University, 4400 Massachusetts Ave, NW, Washington, D.C. 20016-8007. E-mail: ctudge@american.edu

(MB) Department of the Environment, P.O. Box: 5181, Tehran, Iran. E-mail: Lahijanjan@yahoo.com

\begin{abstract}
Mud shrimps (formerly Thalassinidea) are common burrow dwelling decapod crustaceans in the littoral zone of the Persian Gulf and Gulf of Oman. Their burrow morphology was investigated using foam casting methods. The present study shows that the burrow morphology in Upogebia carinicauda is not consistent and the recorded variations are based on habitat type and some physical characteristics of sediments. Adult burrow morphology in sandy-muddy substrate with shells, and boulder field habitats were Y-shaped and complex burrows of horizontal channels with turning chambers and vertical connections to internal passages or crevices of boulders, respectively. In burrows of $U$. carinicauda, some narrow passages, connected to the upper part of adult burrows in sandy-muddy habitats, belong to juveniles. Another species, Neocallichirus jousseaumei was found under boulders in sandy-muddy habitats of the Gulf of Oman and Qeshm Island, Persian Gulf. Since this type of habitat is special in some features, no conspicuous ex-current openings (usually obvious as conical mounds of extruded sediment) have been observed on the sediment surface; as these were hidden among the boulders surrounded by mixed sand and shells. The only method for observing this type of burrow was to remove the boulders by hand or lever.
\end{abstract}

Key Words: Foam casting, Upogebia carinicauda, Neocallichirus jousseaumei, Qeshm Island, sandy-muddy habitat

\section{INTRODUCTION}

Recent attempts have been made to document global mud shrimp diversity (Dworschak, 2005; Sakai, 2011). The Persian Gulf and Gulf of Oman are one of the most important regions in the world because of the high volume of oil transport by sea. Despite this maritime importance, there are few studies on marine environments and biodiversity of these coasts. Recent developments of fishing docks and construction of ports on the Iranian coast resulted in the destruction of many habitats in the region. Hence, comprehensive studies prior to any habitat change in the region should be carried out. Key vulnerable organisms, such as mud shrimps, among others, are constantly exposed to these dangers as a result of habitat destruction. The axiidean and gebiidean mud shrimps have worldwide distributions in all oceans from temperate, tropical and subtropical coasts (Dworschak, 2000). Previous studies devoted to taxonomic works on mud shrimps 
of the Persian Gulf include Sakai and Türkay (1995), Dworschak (2009), Sepahvand and Sari (2010), Naderloo and Türkay (2012) and more recently Sepahvand et al. (2013). Based on these studies, 12 species of gebiidean and axiidean mud shrimps are recorded from the Iranian coasts. These belong to three families including Upogebiidae (Upogebia carinicauda, U. darwinii, U. pseudochelata, U. savignii), Callianassidae (Neocallichirus jousseaumei, N. calmani, Callichirus masoomi, Corallianassa coutierei, Michaelcallianassa indica, Paratrypaea bouvieri and Gourretia coolibah) and Callianideidae (Callianidea typa). Burrowing by mud shrimps in the intertidal region of studied areas is extensive and acts as a powerful source of bioturbation, particularly in sandy-muddy substrates. The coastal region along Qeshm Island, Persian Gulf and Gulf of Oman is composed of a diverse range of habitats, which are home to various crustaceans including ubiquitous mud shrimps. According to Dworschak et al. (2012) burrow morphology varies in different families and genera, from the simple U- or Y-shaped structure for members of the Upogebiidae to complex burrow patterns with chambers and branches; such as those seen in the Callianassidae.

Berkenbusch and Rowden (2000) suggested that some parameters such as seawater temperature and organic content of the sediment influence the burrow morphology of callianassid mud shrimps, while earlier, Griffis and Chavez (1988) suggested that burrow morphology was related to sediment type in two eastern Pacific species of callianassid. Biological factors, such as population density and competition with associated macroinfauna, have also been suggested to influence burrow morphology (Nash et al., 1984). Butler and Bird (2008), studied the burrow morphology of two callianassid shrimp species and found that the overall burrow morphology of both was consistent over time, but burrow depth and volume are greater in warmer than cooler months. The variation in burrow shape in a number of gebiidean and axiidean mud shrimp species has been reviewed by de Vaugelas
(1990) and Griffis and Suchanek (1991) who showed that their burrows can be categorized into four groups based on feeding types and the additional appearance of the burrow openings and six groups based on their morphological characteristics, respectively. According to Astall et al. (1997), the burrows are mostly similar in congeneric species. Our knowledge of mud shrimp burrow morphology, in the last decade, relies on the studies reviewed in Dworschak et al. (2012). The purpose of the current study is to describe the burrow structure in different habitats of Qeshm Island for a gebiidean, Upogebia carinicauda (Stimpson, 1860), using foam casting and direct exposure of burrows. In addition, these burrow types were compared to an axiidean, Neocallichirus jousseaumei (Nobili, 1904) in some habitats in the Gulf of Oman.

\section{Material and Methods}

The present study was carried out in three localities in the littoral zone of differing habitats (Fig. 1). The first was at Tis estuary, Chabahar Bay (25 21' $\left.10^{\prime \prime} \mathrm{N}, 60^{\circ} 36^{\prime} 08^{\prime \prime} \mathrm{E}\right)$, the second one was in the vicinity of the Laaft desalination

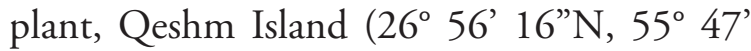
$\left.48^{\prime \prime} \mathrm{E}\right)$ and third was located at Zeyton Park (27 11'06”N, 56 24' 11'E). Chabahar Bay is composed of sandy-muddy habitat with boulders and shell fragments, Laaft has sandymuddy substrate with shell fragments only, and Zeyton Park has a limestone aggregate rock substrate. Dworschak et al. (2012) reviewed some methods used to study the burrowing patterns of mud shrimps, such as resin casting, keeping individuals in narrow aquaria and careful digging to trace burrows, but each method has some limitations. Using poured resin in intertidal areas for narrow burrow channels was unsuccessful and digging in some areas with loose substrate proved an unsuitable method. So, here we propose using injectable polyurethane foam as an alternative method for intertidal zones; although caution against using expandable foam in very soft sediments that may deform the burrow architecture. In order to study the burrow morphology of Upogebia carinicauda, expanding polyurethane 


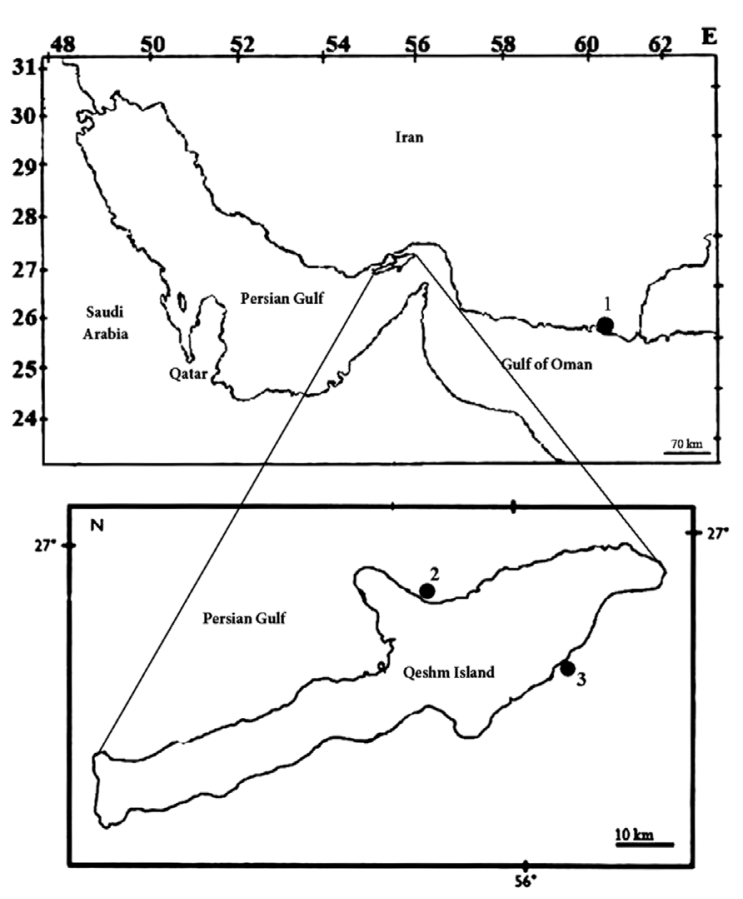

Figure 1. Map of sampling localities: 1) Tis Estuary, Chabahar Bay, Gulf of Oman, 2) Laaft desalination plant, Qeshm Island, and 3) Zeyton Park, Qeshm Island, Persian Gulf.

foam (Apel', multi-purpose PU foam) was injected into the burrows in the summer of 2011. After foam injection into the burrow entrance, while the foam was still expanding, the burrow opening was covered by a nearly flat piece of rock or a brick to facilitate its penetration down into the burrow canals. This helped to avoid total foam escape from the burrow entrance. But, later, the excess foam leaked from the burrow opening onto the surface, from under the covering rock or brick, after filling all the burrow cavities. One hour after injection, when the foam had hardened, the now solid burrow casts were removed by digging. The depth of each burrow cast was measured as the straight line of vertical distance from the burrow opening to burrow end based on the hardened injected foam. The horizontal extension was measured as a straight horizontal line from two ends of foam casts. Photographs of burrow structure were taken using a digital camera and in total 12 burrow casts were examined. In the laboratory burrow diameter was measured based on four hardened and completely expanded foam casts using a Vernier caliper. For comparison, photographs taken of burrow openings of Upogebia carinicauda, from the same locality at Laaft desalination plant in the exceptionally cold year of 2008, were also used in this study. Due to difficulties of foam injection into burrows in a sandy-muddy area with shells and boulders at Chabahar Bay, Gulf of Oman, only two injection attempts were successful and these limited data are still presented here.

\section{Results}

Foam casts of burrows in sandy-muddy substrate with abundant shells at Laaft desalination plant, Qeshm Island (locality 2, Fig. 1) were obtained for Upogebia carinicauda. From 12 of these burrows, nine complete foam casts were obtained, of which four were used for drawings. Measurements for diameter, height and turning chamber were obtained from the complete foam casts and the three remaining incomplete ones. Data from Zeyton Park (locality 3, Fig. 1) was taken from five direct observations in the limestone bedrock aggregate, as foam injection was not possible). All burrows varied from $12-17 \mathrm{~mm}$ in diameter, $22-30 \mathrm{~cm}$ in depth, and reached a maximum horizontal extension of $37 \mathrm{~cm}$. Most burrows in the sandy-muddy substrate are either a simple branched "Y" or a multi-branched Y-shape. In rocky habitats, with a unique texture of multilayered limestone bedrock, many channels from previous burrow activities of other animals and the added effect of water erosion were noticed (Fig. 2A). The usual two surface burrow openings (in-current and ex-current) were not obvious in this type of burrow and so calcium carbonate rocks were broken open, using a hammer, in order to find the specimens and reveal their burrow architecture (Fig. 2B). The type of burrow in limestone bedrock was a single U-shape possessing two shafts with equal branches, but there was usually a bulbous turning chamber in at least one of the shafts (Figs. 2B, 4D). These burrows varied from 10 to $13 \mathrm{~mm}$ in diameter, $10-15$ $\mathrm{cm}$ in depth, and up to $22 \mathrm{~cm}$ in horizontal extension. The turning chamber size was $12-$ $18 \mathrm{~mm}$ in diameter. In the sandy-muddy area 

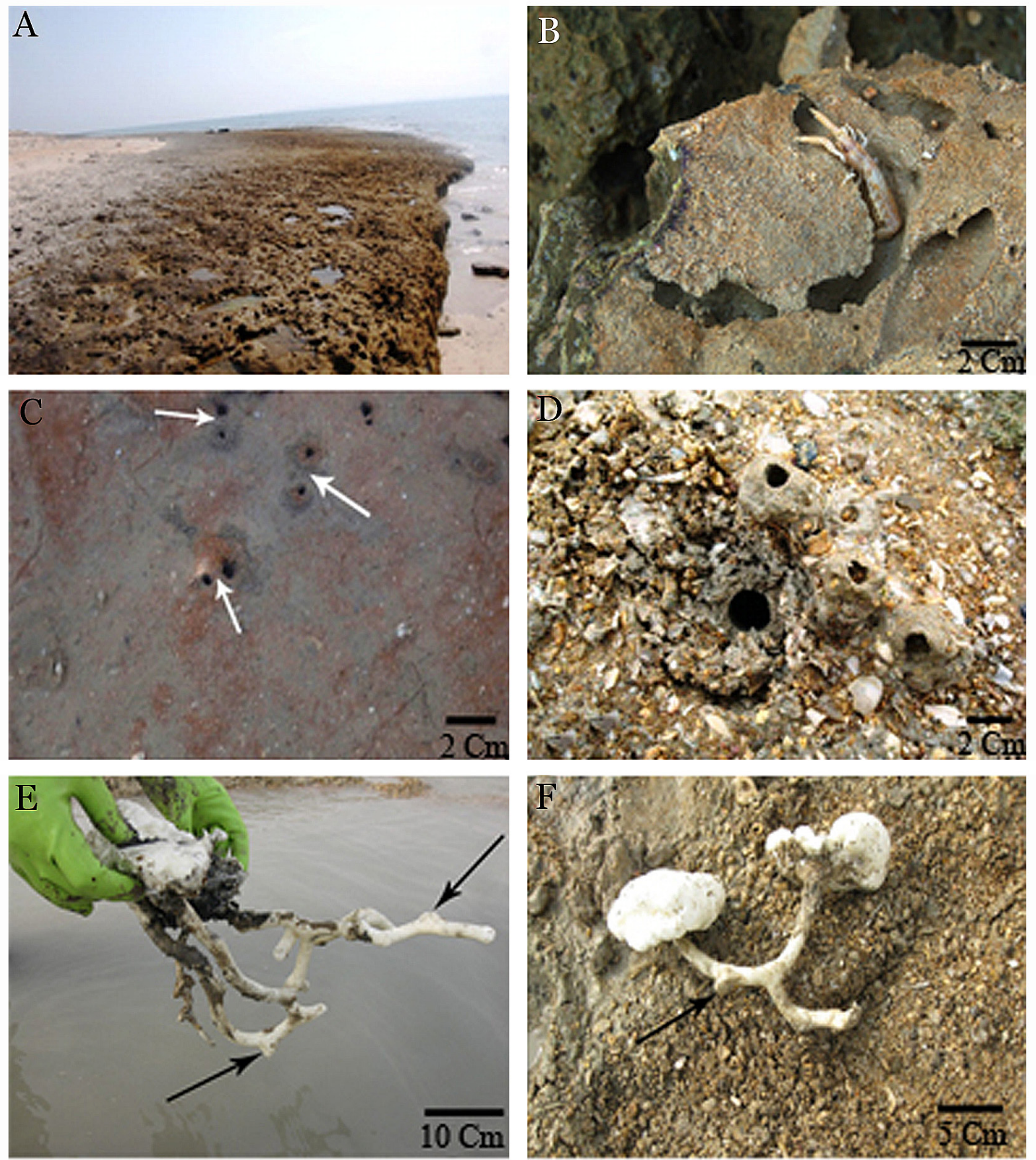

Figure 2. Upogebia carinicauda (A-F), (A) general view of habitat type; (B) burrow structure inside a broken rock; (C) burrow opening in spring and summer in sandy-muddy habitats with shell fragments, white arrows demarcate chimney sediments; (D) burrow opening in winter from same locality, the upper part of the sediment is removed to show the actual diameter of burrow; (E) and (F) foam casts in sandy-muddy substrate with shells, black arrows indicate burrow turning chamber.

with shell fragments having gently sloping coastal habitats, numerous openings belonging to other burrowing animals were observed, including polychaetes, mantis shrimps and brachyuran crabs. This made it difficult to distinguish the burrow openings of the mud shrimp, but the presence of two closely located chimneys of agglutinated sediments of burrow wall at the burrow openings provided an easy locating guide. The chimney sediments were darker brown than the surrounding sediment (Fig. 2C) and each burrow was occupied by a single adult only. In some cases, burrows are Y-shaped or consist of a simple "U"-shape or multiple connected "U"-shapes with some connecting shafts (Fig. 2E). Occasionally, the 

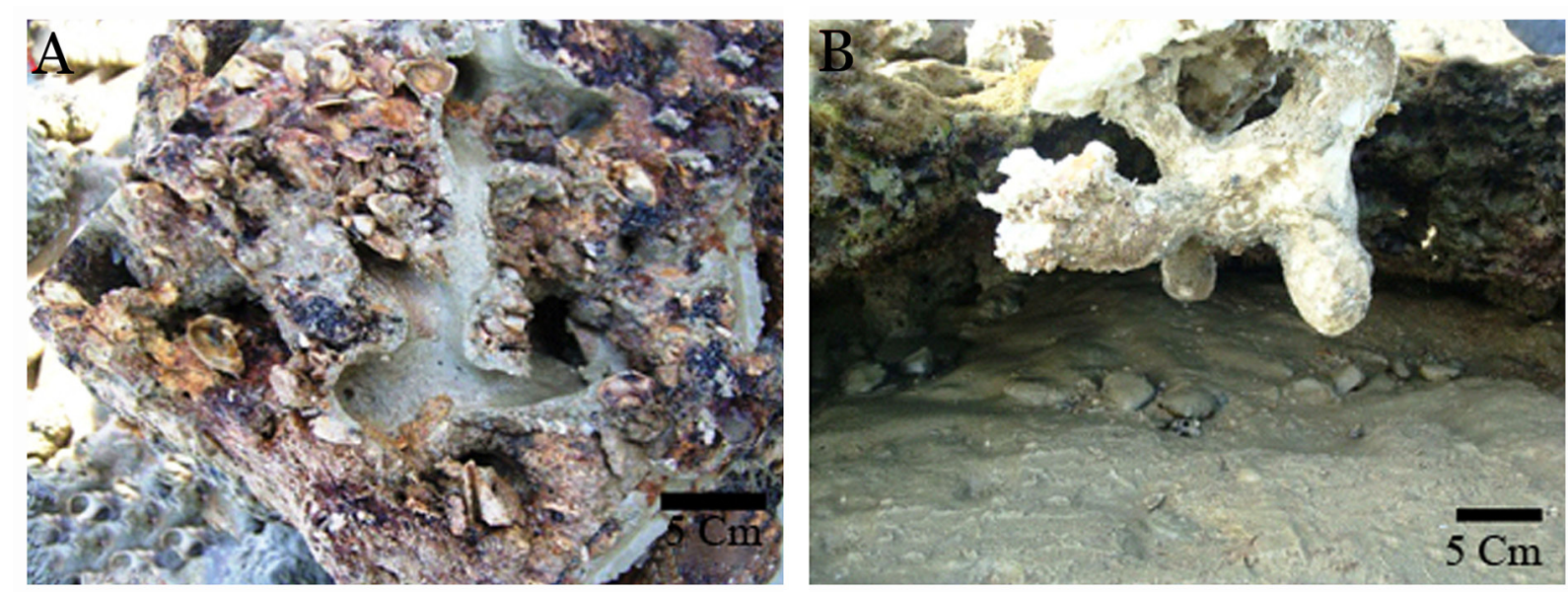

Figure 3. (A) Neocallichirus jousseaumei burrow morphology in a limestone habitat; (B) foam cast for Neocallichirus jousseaumei showing burrow type in sandy-muddy habitat with shell fragments under boulders.

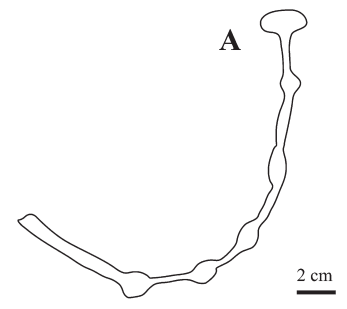

C

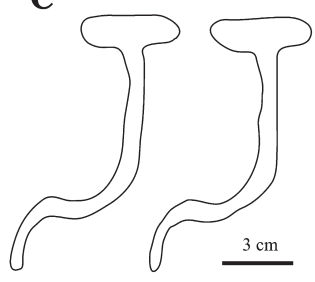

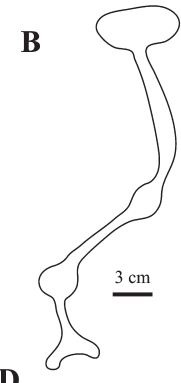

D

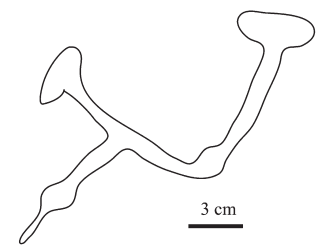

Figure 4. Burrow morphology drawings from foam casts. Upogebia carinicauda burrows consist of either a single oblique shaft (A), (B) and (C) or Y-shaped burrows with curved shafts (D).

main tunnel branches become enlarged at the intersections and the distal ends of these branches are narrowed. The angles between branches at each junction are always more than $90^{\circ}$ (Fig. 2F). In the Y-shaped burrows, there is usually only one turning chamber on one side branch. In contrast, these were mostly with multiple turning chambers in burrows with simple vertical shaft (Fig. 4A, 4B) but a few shallow burrows were observed as a simple oblique shaft (Fig. 4C). In the case of multiple U-shapes, the pattern of the burrow is more complex - usually these are connected to each other, and the number of turning chambers is greater. In five cases, a lateral oblique passage was connected to the main U-type burrows

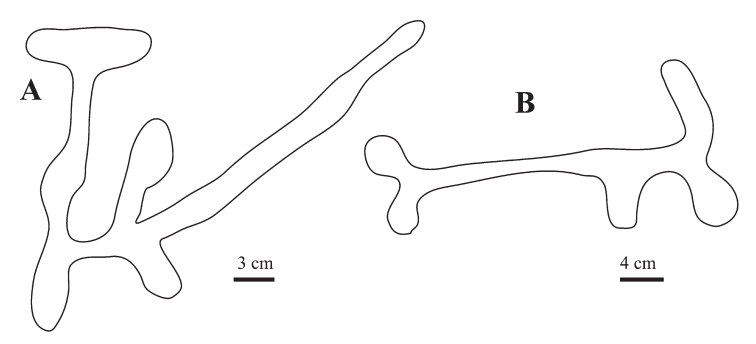

Figure 5. Burrow morphology drawings from foam casts. Neocallichirus jousseaumei complex burrows of horizontal channels with turning chambers (A) and (B).

and juveniles were occasionally observed in these narrow passages (Fig. 2E). In the winter of 2008, at the same locality, the weather was exceptionally cold with minimum temperatures close to $2{ }^{\circ} \mathrm{C}$ at Qeshm Island. Several hundred burrow openings were observed within $1 \mathrm{~m}^{2}$ in a closely arranged cylindrical form with an elevated muddy dome-shaped rim at the narrow entrance (some are detailed in Fig. 2D). One of these rims was removed to show the actual diameter of the main shaft $(15 \mathrm{~mm})$ which ended as a straight shaft with a turning chamber at the lowest point. At low tide, a single individual shrimp was found resting within the terminal turning chamber of each burrow.

The burrow morphology of Neocallichirus jousseaumei involves complex horizontal channels with turning chambers which resemble the U-shaped type of burrows (Figs. 3, 5) but the surface burrow openings are not visible due to a lack of surrounding mound sediment. This species prefers sandy- 
muddy habitats with shells and limestone boulders and uses mud to cover burrow walls including the passages attached to the boulder (Fig. 3A). The burrow has a broader chamber at the crossing point of the two tunnels (Fig. 3B). There is usually one specimen in each burrow, but occasionally a male and female are found together in one burrow, but no more than two specimens were observed in each burrow. The diameter of the burrows is usually between 20 and $30 \mathrm{~mm}$ but in the turning chamber it is wider, up to $35 \mathrm{~mm}$ in diameter. The inner wall of the burrow is smooth and soft, covered by mud, and there is no sign of any debris, such as sea grass in the wall.

\section{Discussion}

There are a number of studies on burrow morphology and burrowing habits of gebiidean and axiidean mud shrimps (see Dworschak et al., 2012 for review). The burrow types of these mud shrimps in the Gulf of Oman and Qeshm Island region can be divided into two groups based on the presence or absence of surface mounds (Sepahvand and Sari, 2010). The first group includes four species - Upogebia carinicauda, Paratrypaea bouvieri, Callichirus masoomi, and Michaelcallianassa indica - which occupy sandy-muddy substrate with shell fragments and usually have two sediment chimneys demarcating the openings. The second burrow type lacks any surface sediment mounds and can be seen in different habitats. Example species include - Neocallichirus jousseaumei and Gourretia coolibah which live under boulders, Upogebia pseudochelata and Callianidea typa which occupy existing cavities and wide crevices of rocks, and Upogebia darwinii which prefers internal canals of sponges in the same rock. As stated by Griffis and Chavez (1988), burrow size and morphology may vary with local environmental conditions, such as sediment type and tidal height, or with biological factors, such as population density and community composition. However, according to Dworschak and Ott (1993), usually assigning any particular burrow morphology to a species is difficult and that burrow shapes are related to both phylogenetic affinities and ecological adaptation. The greatest diversity in burrow morphology on Iranian coasts exists among the genus Neocallichirus, with simple Y-shaped burrows with two chimneys on ex-current surface openings found in $N$. calmani and complex burrows with side shafts and turning chambers found in $N$. jousseaumei that live under boulders (present study). De Vaugelas (1990) categorized the burrow morphology into four types using food type and shape of openings including: I) omnivorous and mostly isolated from surface, II) detritivorous having large mounds, III) suspension-deposit feeder and openings with small mounds, and IV) suspension feeders. Using the burrow morphology classification system of de Vaugelas (1990), the candidate species in this study, $U$. carinicauda and $N$. jousseaumei are categorized into their type IV and III, respectively. Griffis and Suchanek (1991) classified burrows into six groups based on presence and absence of opening mounds and sea grass deposits and also using characteristics of burrows: I) tiered galleries, II) simple branches, III) simple chambers, IV) deep reticulated, V) Y-shaped and VI) U-shaped. Similar to other upogebiids, the burrow architecture of Upogebia carinicauda agrees with a general pattern of upogebiids having simple burrows with U-shaped upper sections. However, the pattern of burrowing in $U$. carinicauda in sandy-muddy habitats resembles that of $U$. stellata (Fig. 1B) and $U$. deltaura (Fig. 1D, 1I) burrows (see Astall et al., 1997). A deviation from this general pattern was observed in the exceptionally cold winter of 2008, in which a simple vertical burrow with a turning chamber in the lower part was prevalent. This is considered variation due to environmental condition as stated by Dworschak et al. (2012). But, if one follows the Griffis and Suchanek (1991) classification, $U$. carinicauda (those that live in sandymuddy habitats) is categorized into their type $\mathrm{V}$ but $N$. jousseaumei could not be attributed to any group. Their model was criticized by Dworschak and Ott (1993) due to a lack of 
applicability to all species. But, with careful examination of his figure 4.8 for Callichirus sp. aff. jousseaumei (now Neocallichirus vaugelasi Dworschak, 2011) presented by De Vaugelas (1990), the middle part of burrow structure shows close similarity to the burrow type for $N$. jousseaumei from the Gulf of Oman. It seems that this type of burrow in $N$. jousseaumei from the Gulf of Oman is related to the nature of habitat in these axiid shrimps, as they live in a boulder field. This species lives under boulders and builds their burrows among shells and cobbles and therefore showing similar type of digging as $N$. vaugelasi from Aqaba, Red Sea (See De Vaugelas, 1990). The burrow walls are lined with mud from available soft sediments of lower layers. Sometimes, they connect their burrows to already existing passages within the boulder and cover the stony wall with mud. Similarly, individuals of boulder field dwelling species Pestarella whitei and Nihonotrypaea petalura wind their burrows among boulders and cobbles (see Dworschak et al., 2012).

Despite taxonomic studies of these species in the North West Indian Ocean, the burrow structure is poorly known in this area, with the exception of studies carried out by de Vaugelas and Saint-Laurent (1984), de Vaugelas (1985) and Dworschak and Pervesler (1988), which focused on the Red Sea. Ecological and behavioral characteristics (see Mayr and Ashlock, 1991), in addition to morphological ones, are equally as important for species identification, and therefore, characteristics such as feeding habits and burrow morphology should be taken into account. It is likely that the observed variation in burrow morphology for $U$. carinicauda is related to substrate type, which was mostly Y-shaped in the sandymuddy substrate with shell fragments and U-shaped in limestone aggregate bed rock habitat. In the present study, dissimilarities between $N$. jousseaumei and $U$. carinicauda burrows were significantly related to body size, substrate type and their phylogenetic affinity. According to Dworschak (1983) there are high levels of variation in burrow morphology for a number of mud shrimps. Some authors, such as Nickell and Atkinson (1995), believe that particular burrow features most likely relate to feeding strategies. Berkenbusch and Rowden (2000) suggested that the variation in burrow morphology of Biffarius (as Callianassa) filholi, in New Zealand waters is linked to seawater temperature and/or sediment organic content. Similarly, Griffis and Chavez (1988) suggested that sediment type and environmental factors such as tidal height and tidal exposure influenced the depth and burrow morphology of Neotrypaea (as Callianassa) californiensis and $N$. gigas in the Eastern Pacific.

In conclusion, it is suggested that burrow type in these two Iranian representative axiidean and gebiidean species is more related to sediment type and their phylogenetic affinity. The intraspecific variations found within individuals of $U$. carinicauda are regarded as seasonal variation based on observation in the summer of 2011 and previous data and observations (by AS) from the winter of 2008. But, generally it follows the gebeiid type of burrow. This shows phylogenetic affinity as shown by Dworschak and Ott (1993) but Dworschak et al. (2012) stated that there is variability in burrows of the genus Neocallichirus. Interspecific variability of $N$. jousseaumei from the current study, along with its allied species $N$. vaugelasi from Aqaba, Red Sea, is related to habitat differences (ecological adaptation mentioned by Dworschak and Ott, 1993). But, because of the small sample size, we do not disregard the influence of other factors on burrow type, and suggest that the effects of seasonal variation, population density and organic content of the substrate may influence burrow morphology of $U$. carinicauda and $N$. jousseaumei. Investigations of these environmental factors are all areas for future research on these species.

ACKNOWLEDGEMENTS - The authors express their gratitude to Dr. Peter Dworschak for his help on several occasions. Special thanks to Mr. Abbas Kazemi for his help during field studies. The study was financially supported by the Department of Environment and Research Council, University of Tehran, Iran. The comments of several anonymous reviewers greatly improved this contribution. 


\section{REFERENCES}

Astall, C.M.; Taylor, A.C and Atkinson, R.J.A. 1997. Behavioral and physiological implications of a burrow-dwelling lifestyle for two species of upogebiidean mud-shrimp (Crustacea: Thalassinidea). Estuarine, Coastal and Shelf Science, 44:155-168.

Berkenbusch, K. and Rowden, A.A. 2000. Intraspecific burrow plasticity of an intertidal population of Callianassa filholi (Crustacea: Decapoda: Thalassinidea) in relation to environmental conditions. New Zealand Journal of Marine and Freshwater Research, 34(3): 397-408.

Butler, S.N. and Bird, F.L. 2008.Temporal changes in burrow structure of the thalassinidean ghost shrimps Trypaea australiensis and Biffarius arenosus. Journal of Natural History, 42: 2041-2062.

Dworschak, P.C. 1983. The biology of Upogebia pusilla Petagna (Decapoda, Thalassinidea). I. The burrows. Publicazioni della Stazione Zoologica di Napoli I: Marine Ecology, 4(1): 19-43.

Dworschak, P.C. 2000. Global diversity in the Thalassinidea (Decapoda). Journal of Crustacean Biology, 20(2): 238-245.

Dworschak, P.C. 2005. Global diversity in the Thalassinidea (Decapoda): an update (1998-2004). Nauplius, 13(1): 57-63.

Dworschak, P.C. 2009. On a small collection of thalassinidean shrimp (Crustacea: Decapoda) from Qatar (Persian-Arabian Gulf). Annalen des Naturhistorischen Museums in Wien, 110 B: 129137.

Dworschak, P.C. 2011. Redescription of Callianassa jousseaumei Nobili, 1904, a junior subjective synonym of Callianassa indica De Man, 1905 with description of a new species of Neocallichirus (Decapoda: Axiidea: Callianassidae). Zootaxa, 2746: 1-19.

Dworschak, P.C. and Ott, J.A. 1993. Decapod burrows in mangrove channel and back-reef environments at the Atlantic Barrier Reef, Belize. Ichnos, 2: 277-290.

Dworschak, P.C. and Pervesler, P. 1988. Burrows of Callianassa bouvieri Nobili 1904 from Safaga (Egypt, Red Sea) with some remarks on the biology of the species. Senckenbergiana Maritima, 20: 1-17.

Dworschak, P.C.; Felder, D.L. and Tudge, C. 2012. Infraorders Axiidea de Saint Laurent, 1979 and Gebiidea de Saint Laurent, 1979 (formerly known collectively as Thalassinidea). p. 109-219. In: Schram, F.R., Vaupel Klein, J.C., von, Forest, J. \& Charmantier-Daures, M. (eds), Treatise on Zoology - Anatomy, Taxonomy, Biology. The Crustacea. Complementary to the volumes translated from the French of the Traité de Zoologie [founded by P.-P. Grassé], Volume 9 Part B. Brill, Leiden,

Griffis, R.B. and Chavez, F.L. 1988. Effects of sediment type on burrows of Callianassa californiensis Dana and C. gigas Dana. Journal of Experimental Marine Biology and Ecology, 117: 239-253.

Griffis, R.B. and Suchanek, T.H. 1991. A model of burrow architecture and trophic modes in thalassinidean shrimp (Decapoda: Thalassinidea). Marine Ecology Progress Series, 79: 171-183.

Mayr, E. and Ashlock, P.D. 1991. Principles of Systematic Zoology, Harvard University Press, 475 pp.

Naderloo, R. and Türkay, M. 2012. Decapod crustaceans of the littoral and shallow sublittoral Iranian coast of the Persian Gulf: Faunistics, Biodiversity and Zoogeography. Zootaxa, 3374: 1-67.
Nash, R.D.M.; Chapman C.J.; Atkinson, R.J.A. and Morgan, P.J. 1984. Observations on the burrows and burrowing behaviour of Calocaris macandreae (Crustacea, Decapoda, Thalassinoidea). Journal of Zoology, 202: 425-439

Nickell, L.A and Atkinson, R.J.A. 1995. Functional morphology of burrows and trophic modes of three thalassinidean shrimp species, and a new approach to the classification of thalassinidean burrow morphology. Marine Ecological Progress Series, 128(1-3): 181-197.

Sakai, K. 2011. Axioidea of the World and a reconsideration of the Callianassoidea (Decapoda, Thalassinidea, Callianassida). Crustacean Monographs, 13: 1-616.

Sakai, K. and Türkay, M. 1995. Two upogebiidean species from the Persian-Arabian Gulf, with the description of a related new species from Taiwan (Crustacea: Decapoda: Upogebiidae). Senckenbergiana Maritima, 25(4/6): 197-208.

Sepahvand, V. and Sari, A. 2010. Taxonomy and geographical distribution of intertidal thalassinidean shrimps (Crustacea: Decapoda) from Qeshm Island, Persian Gulf. Journal of Science, University of Tehran, 36(2): 43-52.

Sepahvand, V.; Sari A.; Salehi, H.; Nabavi, S. and Ghorbanzadeh, S. 2013. Littoral mud shrimps (Decapoda: Gebiidea \& Axiidea) of the Persian Gulf and Gulf of Oman, Iran. Journal of the Marine Biological Association of the United Kingdom, 93(4): 999-1008.

Vaugelas, J. V. de and Saint-Laurent, M. 1984. Premieres donnees sur l'ecologie de Callichirus laurae de Saint Laurent sp. nov. (Crustace Decapode Callianassidae) son action bioturbatrice sur les formations sedimentaxes du golfe d'Aqaba (Mer Rouge). Comptes rendus de l'Academie des Sciences, Paris (Ill), 298: 147-152.

Vaugelas, J.V. de 1985. Sediment reworking by callianassid mud shrimp in tropical lagoons: a review with perspectives. In: M. Harmelin-Vivien, B. Salvat \& C. Gabarie (eds) Proceeding of Vth International Coral Reef Congress, Papetee, Tahiti, 6: 617-620 (Antenne Museum Ephe, Papeete, Tahiti).

Vaugelas, J.V. de. 1990. Ecologie des callianasses (Crustacea, Decapoda, Thalassinidea) en milieu recifal Indo-Pacifique. Consequences du remaniement sedimentaire sur la distribution des matieres humiques, des metaux traces et des radionucleides. Doctoral d' Habilitation, Université 6 de Nice. 226 pp. 